
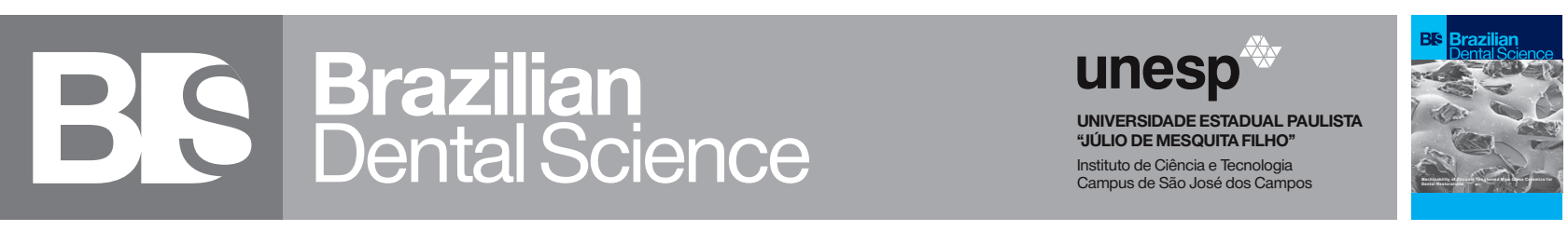

\title{
Comparative evaluation of antimicrobial potential of herbal extracts on Streptococcus mutans and Enterococcus faecalis An in vitro study
}

Avaliação comparativa do potencial antimicrobiano de extratos de ervas em Streptococcus mutans e Enterococcus faecalis: estudo in vitro

Pranati TATEKALVA ${ }^{1}$, Haripriya SUBBAIYAN ${ }^{1}$, Shanmugam Rajesh KUMAR ${ }^{1}$

1 - Saveetha Dental College, Saveetha Institute of Medical and Technical Sciences, Saveetha University, Chennai, India.

\begin{abstract}
Though aloe vera extract, green tea extract and coriander oil are proven antimicrobial agents, very little information is available regarding its effects on oral bacteria, Streptococcus mutans, which is responsible for initiating caries and Enterococcus faecalis, responsible for failure of root canal treatment. Objective: To find the antimicrobial activity of aloe vera extract, black tea extract and coriander oil against $S$. mutans and E. faecalis. Materials and Methods: The agar well diffusion method was used to determine the antibacterial activity of Aloe vera extract, black tea extract and coriander oil. Different concentration of prepared plant extracts and coriander seed oil (50 \& 100 $\mu l)$ was incorporated into the wells and the plates containing $S$. mutans and $E$. faecalis were incubated at $37{ }^{\circ} \mathrm{C}$ for $24 \mathrm{~h}$. The antibiotic (amoxicillin 30 $\mu \mathrm{l}$ ) was used as positive control. Zone Of Inhibition (ZOI) was recorded in each plate. Results: For $S$. mutans, the maximum ZOI was created by coriander oil with a diameter of $25.00 \pm 0.58 \mathrm{~mm}$ at $50 \mu \mathrm{l}$ and for E. faecalis, maximum ZOI was created by aloe vera extract $16.00 \pm 0.58 \mathrm{~mm}$ at $100 \mu \mathrm{l}$ concentration which were far better than the control: amoxicillin $30 \mu \mathrm{l}$ concentration. Conclusion: The extracts of Aloe vera, black tea and coriander oil, showed significant activity against the investigated microbial strains, Streptococcus mutans and Enterococcus faecalis which further helps in the development of new topical agents that help in reducing the numbers of these organisms present in the oral cavity.
\end{abstract}

\section{KEYWORDS}

Oral microbiota; Aloe vera; black tea; coriander oil; E. faecalis; S.mutans.

\section{RESUMO}

Embora o extrato de aloe vera, extrato de chá verde e óleo de coentro sejam agentes antimicrobianos comprovados, há pouca informação disponível sobre seus efeitos nas bactérias orais, Streptococcus mutans, que é responsável por iniciar cáries e Enterococcus faecalis, responsável pela falha do tratamento de canal radicular. Objetivo: Avaliar a atividade antimicrobiana do extrato de aloe vera, extrato de chá preto e óleo de coentro contra $S$. mutans e E. faecalis. Materiais e Métodos: O método de difusão em agar foi usado para determinar a atividade antibacteriana do extrato de Aloe vera, extrato de chá preto e óleo de coentro. Diferentes concentrações dos extratos de plantas e óleo de semente de coentro (50 e $100 \mu \mathrm{l})$ foram preparados e colocados nos poços e nas placas contendo $S$. mutans e $E$. faecalis e foram incubadas a $37^{\circ} \mathrm{C}$ por $24 \mathrm{~h}$. O antibiótico (amoxicilina $30 \mu \mathrm{l}$ ) foi utilizado como controle positivo. A zona de inibição (ZOI) foi registrada em cada placa. Resultados: Para $S$. mutans, a ZOI máxima foi obtida com o óleo de coentro com um diâmetro de 25,00 \pm 0,58 mm a 50 $\mu \mathrm{l}$ e para $E$. faecalis, a ZOI máxima foi obtiada pelo extrato de aloe vera $16,00 \pm 0,58 \mathrm{~mm}$ na concentração de $100 \mu \mathrm{l}$, as quais foram melhores do que o controle: concentração de $30 \mu \mathrm{l}$ de amoxicilina. Conclusão: Os extratos de Aloe vera, chá preto e óleo de coentro apresentaram atividade significativa contra as cepas microbianas investigadas, Streptococcus mutans e Enterococcus faecalis auxiliando no desenvolvimento de novos agentes tópicos visando a redução do número desses organismos presentes no cavidade oral.

\section{PALAVRAS-CHAVE}

Microbiota oral; Aloe vera; Chá preto; Oleo de coentro, Streptococcus mutans, Enterococcus faecalis. 


\section{INTRODUCTION}

D ental caries is the localised destruction of susceptible dental hard tissues by acidic byproducts from bacterial fermentation of dietary carbohydrates [1-3]. Dental caries results from an ecological imbalance in the physiological equilibrium between tooth minerals and oral microbial biofilms [4,5]. Endogenous bacteria, mainly Streptococcus mutans, in the biofilm produce weak organic acids as a by-product of metabolism of fermentable carbohydrates. These weak organic acids reduce the local $\mathrm{pH}$ and demineralises the tooth [4-8]. Caries can be arrested and potentially reversed in its early stages, but is often not self-limiting and without proper care, caries can progress until the tooth is destroyed [1]. Although the primary focus of $S$. mutans virulence is in the oral cavity, it can enter into systemic circulation causing bacteraemia leading to infective endocarditis $[9,10]$.

Enterococcus faecalis, is a normal inhabitant of the oral cavity. It's Prevalence is increased in oral rinse samples from patients receiving initial endodontic treatment, those midway through treatment and patients receiving endodontic retreatment when compared to patients with no endodontic history [11]. E. faecalis is associated with different forms of periradicular diseases including primary endodontic infections and persistent infections [12]. According to the literature, E. faecalis in dentinal tubules has been shown to resist intracanal dressings of calcium hydroxide for over 10 days $[13,14]$. E. faecalis has the potential to form biofilm that helps it resist destruction as the bacteria becomes 1000 times more resistant to phagocytosis, antibodies, and antimicrobials than nonbiofilm producing organisms [15].

Use of plants is still being explored and is considered to be a promising treatment option for various diseases [16]. Aloe vera has been used therapeutically for many centuries because of its lengthy historic reputation as a potential curative agent and its widespread use in complementary therapies $[17,18]$. Although a lot of works have been carried out on the medicinal uses of Aloe vera, there is still little information on its antimicrobial effect against carious bacteria.
Tea is a widely consumed beverage and is popularised throughout the world. The growing interest in the potential health benefits of tea, together with its popularity as a beverage, have lead to numerous investigations on the chemical constituents of tea and their biological properties [19], such as antimutagenic [20], anticarcinogenic and antioxidant [21,22], antibacterial [23,24] and antiallergic activities [25].

Coriander sativum (coriander) is a wellknown herb widely used as a spice and in folk medicine [26]. Coriander oil is one among the 20 major essential oils in the world market [27]. It is a known antimicrobial agent but it's mechanism of action is unclear [26,28].

Though the above mentioned plant extracts and essential oil are proven antimicrobial agents, very little information is available regarding its effects on oral bacteria. This study is to determine the antimicrobial activity of aloe vera, black tea and coriander oil against Streptococcus mutans and Enterococcus faecalis using agar gel diffusion method. Different concentrations of the plant materials are used and MIC is determined.

\section{MATERIALS AND METHODS:}

\section{Preparation of plant extract:}

Aloe vera extract preparation: Dried and powdered Aloe vera leaves was purchased. Aqueous extract of Aloe vera was prepared by mixing $5 \mathrm{~g}$ of Aloe vera powder with $100 \mathrm{ml}$ distilled water and was heated at $70{ }^{\circ} \mathrm{C}$ for 5 minutes (Figure 1). The extract was then filtered using Whitman's filter paper. The extract was again heated for 10 minutes and used for further experiments.

Black tea extract preparation: Black tea was purchased from local market and the extract was prepared by mixing $10 \mathrm{~g}$ of black tea powder into $100 \mathrm{ml}$ distilled water. The mixture was then heated at 70 oC for 5 minutes (Figure 2). The solution was filtered using Whitman's paper and is again heated for 10 minutes. The concentrated extract was used for further experiments.

Coriander oil: coriander oil prepared by steam distillation method was purchased from Allin Enterprises, India. 


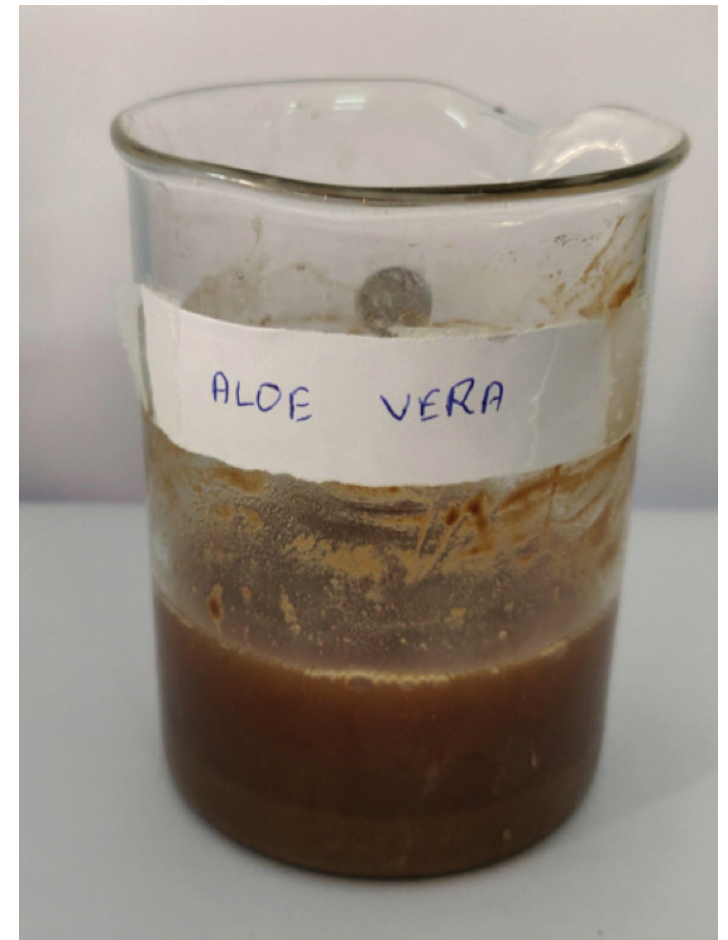

Figure 1 - Mixture of $5 \mathrm{~g}$ of dried Aloe vera leaf powder in 100 $\mathrm{ml}$ distilled water.

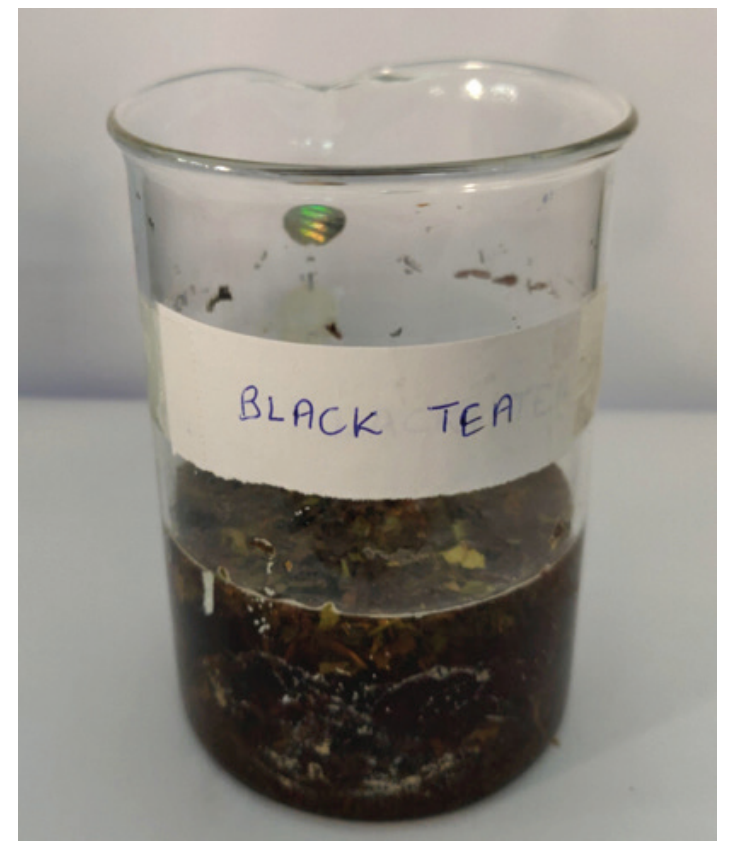

Figure 2 - Mixture of $10 \mathrm{~g}$ of black tea powder in $100 \mathrm{ml}$ distilled water.

\section{Antibacterial activity of plant extracts against oral pathogens:}

The agar well diffusion method was used to determine the antibacterial activity of Aloe vera extract, black tea extract and coriander oil. Different concentrations of the plant extracts and oil was tested against $S$. mutans and $E$. faecalis. The fresh bacterial suspension was dispersed on the surface of Muller Hinton agar plates. Different concentration of prepared plant extracts and coriander seed oil $(50 \& 100 \mu \mathrm{l})$ was incorporated into the wells and the plates were incubated at $37^{\circ} \mathrm{C}$ for $24 \mathrm{~h}$. The antibiotic (amoxicillin $30 \mu \mathrm{l}$ ) was used as positive control. Zone of inhibition was recorded in each plate.

\section{Statistical analysis:}

The ZOI test of each plant extract at 50 and $100 \mu \mathrm{l}$ concentrations was repeated thrice to obtain the triplicate values. The mean, standard deviation and standard error was calculated using the triplicate values.

\section{RESULTS}

Antimicrobial activity of Aloe vera extract, black tea extract and coriander oil at 50 and $100 \mu 1$ concentration against $S$. mutans: Figure 3 and Figure 4

From Table I it is appreciable that the mean ZOI of S. mutans with Aloe vera extract at $50 \mu$ l concentration was found to be $17 \mathrm{~mm}$ with a standard error of $\pm 0.58 \mathrm{~mm}$. And at $100 \mu \mathrm{l}$ it was found to be $20 \mathrm{~mm}$ with standard error of $0.58 \mathrm{~mm}$. Similarly for black tea and coriander oil, the final ZOI was found to be $21.67 \pm 0.88$ $\mathrm{mm}$ and $25.00 \pm 0.58 \mathrm{~mm}$ at $50 \mu \mathrm{l}$ concentration and $24.33 \pm 0.88 \mathrm{~mm}$ and $23.33 \pm 0.58 \mathrm{~mm}$ at $100 \mu$ l concentration respectively. 
Table I- ZOI of aloe vera extract, black tea extract and coriander seed oil against $S$. mutans at 50 and $100 \mu$ respectively obtained by repeating the test 3 different times, the mean ZOI, standard deviation, standard error and the final ZOI (mean \pm standard error) are indicated the table

\begin{tabular}{|c|c|c|c|c|c|c|c|}
\hline \multicolumn{8}{|c|}{ Aloe Vera } \\
\hline & 1 & $\|$ & III & MEAN & STDDEV & STDERR & FINALZOI \\
\hline $50 \mu \mathrm{l}$ & 16 & 17 & 18 & 17.00 & 1 & 0.58 & $17.00 \pm 0.58$ \\
\hline $100 \mu \mathrm{l}$ & 19 & 20 & 21 & 20.00 & 1 & 0.58 & $20.00 \pm 0.58$ \\
\hline \multicolumn{8}{|c|}{ Black tea } \\
\hline & I & $\|$ & III & MEAN & STDDEV & STDERR & FINALZOI \\
\hline $50 \mu \mathrm{l}$ & 20 & 22 & 23 & 21.67 & 1.527525232 & 0.88 & $21.67 \pm 0.88$ \\
\hline $100 \mu \mathrm{l}$ & 23 & 24 & 26 & 24.33 & 1.527525232 & 0.88 & $24.33 \pm 0.88$ \\
\hline \multicolumn{8}{|c|}{ Coriander oil } \\
\hline & 1 & $\|$ & III & MEAN & STDDEV & STDERR & FINALZOI \\
\hline $50 \mu \mathrm{l}$ & 24 & 25 & 26 & 25.00 & 1 & 0.58 & $25.00 \pm 0.58$ \\
\hline $100 \mu \mathrm{l}$ & 22 & 23 & 25 & 23.33 & 1.527525232 & 0.88 & $23.33 \pm 0.58$ \\
\hline
\end{tabular}

Antimicrobial activity of Aloe vera extract, black tea extract and coriander oil at 50 and $100 \mu 1$ concentration against $E$. faecalis: Figure 5 and Figure 6

From Table II it is evident that the mean ZOI of E. faecalis with Aloe vera extract at $50 \mu \mathrm{l}$ concentration was found to be $15.33 \mathrm{~mm}$ with a standard error of $\pm 0.33 \mathrm{~mm}$. And at $100 \mu \mathrm{l}$ it was found to be $16 \mathrm{~mm}$ with standard error of $0.58 \mathrm{~mm}$. Similarly for black tea and coriander oil, the final ZOI was found to be $15.00 \pm 0.58$ $\mathrm{mm}$ and $13.00 \pm 0.58 \mathrm{~mm}$ at $50 \mu \mathrm{l}$ concentration and $18.00 \pm 0.58 \mathrm{~mm}$ and $13.33 \pm 0.58 \mathrm{~mm}$ at $100 \mu \mathrm{l}$ concentration respectively.

Table II - ZOI of aloe vera extract, black tea extract and coriander seed oil against E. faecalis at 50 and $100 \mu \mathrm{l}$ respectively obtained by repeating the test 3 different times, the mean ZOI, standard deviation, standard error and the final $\mathrm{ZOI}$ (mean \pm standard error) are indicated in the table

\begin{tabular}{|c|c|c|c|c|c|c|c|}
\hline \multicolumn{8}{|c|}{ Aloe Vera } \\
\hline & I & $\|$ & III & MEAN & STDDEV & STDERR & FINALZOI \\
\hline $50 \mu \mathrm{l}$ & 15 & 15 & 16 & 15.33 & 0.577350269 & 0.33 & $15.33 \pm 0.33$ \\
\hline $100 \mu \mathrm{l}$ & 15 & 16 & 17 & 16.00 & 1 & 0.58 & $16.00 \pm 0.58$ \\
\hline \multicolumn{8}{|c|}{ Black tea } \\
\hline & I & $\|$ & III & MEAN & STDDEV & STDERR & FINALZOI \\
\hline $50 \mu \mathrm{l}$ & 14 & 15 & 16 & 15.00 & 1 & 0.58 & $15.00 \pm 0.58$ \\
\hline $100 \mu \mathrm{l}$ & 17 & 18 & 19 & 18.00 & 1 & 0.58 & $18.00 \pm 0.58$ \\
\hline \multicolumn{8}{|c|}{ Coriander oil } \\
\hline & 1 & $\|$ & III & MEAN & STDDEV & STDERR & FINALZOI \\
\hline $50 \mu \mathrm{l}$ & 12 & 13 & 14 & 13.00 & 1 & 0.58 & $13.00 \pm 0.58$ \\
\hline $100 \mu \mathrm{l}$ & 12 & 13 & 15 & 13.33 & 1.527525232 & 0.88 & $13.33 \pm 0.58$ \\
\hline
\end{tabular}

Antimicrobial activity of amoxicillin at $30 \mu 1$ concentration against $S$. mutans and $E$. faecalis:

Commercially available concentration of amoxicillin $(30 \mu \mathrm{l})$ used as an antibacterial agent was tested against $S$. mutans and $E$. faecalis. This was used as a positive control. The Mean ZOI and standard error of amoxicillin against $S$. mutans and $E$. faecalis was found to be $14.67 \pm 0.88 \mathrm{~mm}$ and $13.33 \pm 0.58 \mathrm{~mm}$ respectively.

Table III - ZOI of $30 \mu$ of amoxicillin against S. mutans and E. faecalis respectively obtained by repeating the test 3 different times, the mean ZOI, standard deviation, standard error and the final ZOI (mean \pm standard error) are indicated in the table

\begin{tabular}{|lccccccc|}
\multicolumn{2}{|c|}{ Amoxicillin $(\mathbf{3 0} \boldsymbol{\mu L})$} & & & & & \\
& I & II & III & MEAN & STDDEV & STDERR & FINALZOI \\
\hline S. mutans & 13 & 15 & 16 & $\mathbf{1 4 . 6 7}$ & 1.527525232 & 0.88 & $\mathbf{1 4 . 6 7 \pm 0 . 8 8}$ \\
\hline E. faecalis & 12 & 13 & 15 & $\mathbf{1 3 . 3 3}$ & 1.527525232 & 0.88 & $\mathbf{1 3 . 3 3 \pm 0 . 5 8}$
\end{tabular}

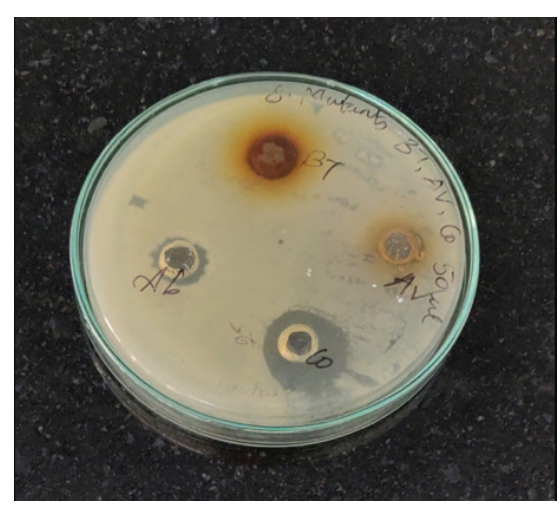

Figure 3 - Muller Hinton agar plate with S. mutans - ZOI of $50 \mu \mathrm{l}$ of AV (Aloe vera extract), BT (Black tea extract), CO (Coriander oil) and $30 \mu \mathrm{Ab}$ (amoxicillin).

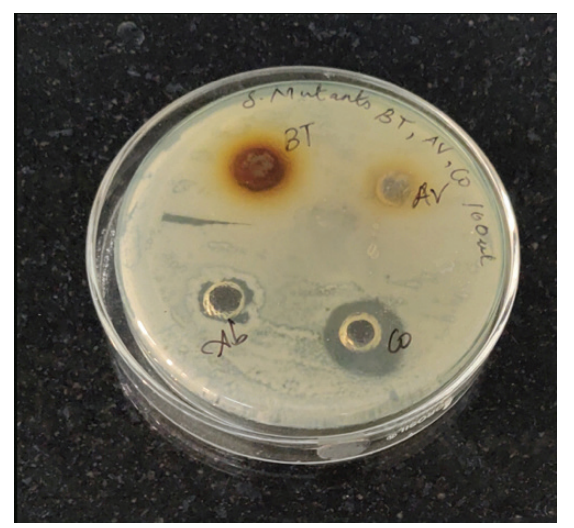

Figure 4 - Muller Hinton agar plate with S. mutans - ZOI of $100 \mu \mathrm{l}$ of $\mathrm{AV}$ (Aloe vera extract), BT (Black tea extract), CO (Coriander oil) and $30 \mu \mathrm{l} \mathrm{Ab}$ (amoxicillin). 


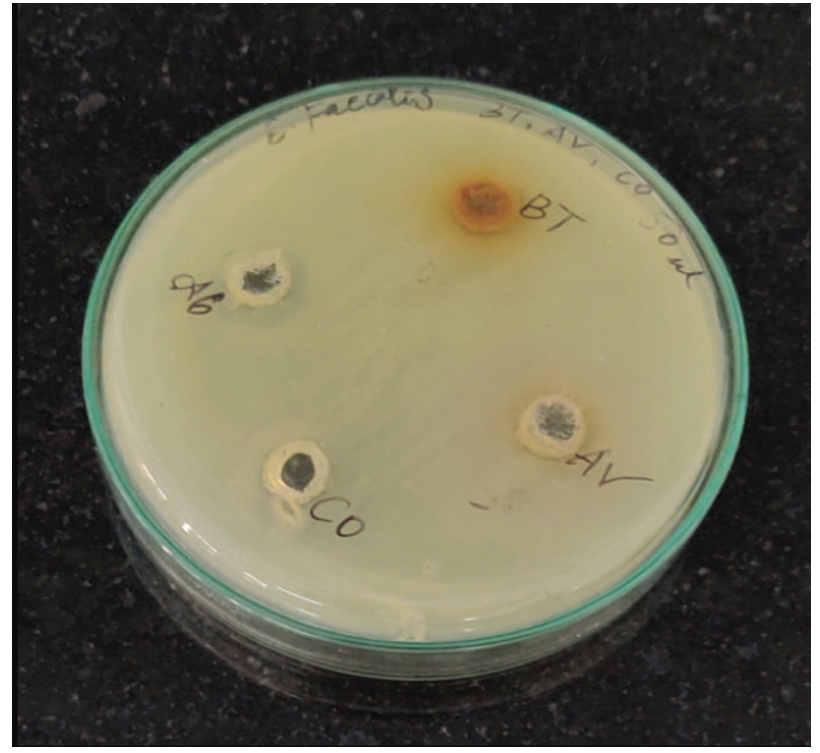

Figure 5 - Muller Hinton agar plate with E. faecalis - ZOI of $50 \mu \mathrm{I}$ of AV (Aloe vera extract), BT (Black tea extract), CO (Coriander oil) and $30 \mu \mathrm{I} \mathrm{Ab}$ (amoxicillin).

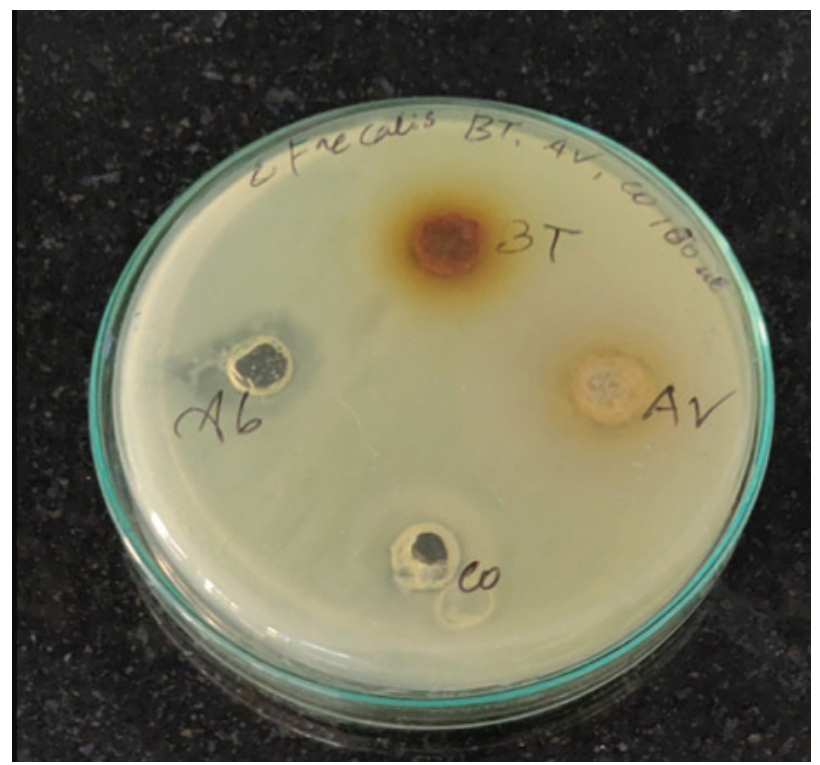

Figure 6 - Muller Hinton agar plate with E. faecalis - ZOI of $100 \mu \mathrm{l}$ of $\mathrm{AV}$ (Aloe vera extract), BT (Black tea extract), CO (Coriander oil) and $30 \mu \mathrm{l} \mathrm{Ab}$ (amoxicillin).

\section{DISCUSSION}

Antimicrobial agents of plant origin have tremendous therapeutic potential. They are effective in the treatment for infectious diseases, and simultaneously they also mitigate many of the side effects that are often associated with synthetic antimicrobials [29]. Hence, the purpose of the present study was to evaluate the role of antimicrobial agents of plant origin in inhibition of the growth of Streptococcus mutans and Enterococcus faecalis.

Studies done by Muangsan et.al., [30] with $P$ granatum and Rani et.al., [31] with 54 medicinal herbs, demonstrated that the antimicrobial activity of the aqueous extracts were as strong as their alcoholic extract. Hence in this study the aqueous extracts of aloe vera and green tea was prepared and used.

In the present study both the plant extracts and essential oil showed good inhibition zones against $S$. mutans ranging from $16-26 \mathrm{~mm}$ and a moderate zone of inhibition against $E$. faecalis ranging from $15-19 \mathrm{~mm}$. This shows the resistance acquired by $E$. faecalis against anti microbial agents. Among the 2 plant extracts and an essential oil, coriander oil was more effective against $S$. mutans with a maximum inhibition zone of $26 \mathrm{~mm}$ at $50 \mu \mathrm{l}$. For E. faecalis, black tea extract was more effective compared to others with maximise inhibitory zone of $19 \mathrm{~mm}$ at 100 $\mu \mathrm{l}$.

The anti-microbial activity of these plant extracts and essential oil was compared with commercially available antibacterial agent amoxicillin. This was used as a positive control. Powdered form of the drug was obtained and $30 \mu \mathrm{l}$ solution was tested against $S$. mutans and E. faecalis. The effect of amoxicillin was more in S. mutans compared to E. faecalis. Both the plant extracts and essential oil had similar antibacterial effect as that of amoxicillin.

The proposed trial of extracts shall result in their clinical validation for the prevention of 
dental caries and secondary infection in post endodontic treated root canals. Clinical proof of efficacy can then be used in the marketing of the plant extracts as therapeutic agent. This shall lead to the commercialisation of these plant extracts, in the form of extracts or oils or even by including them as a key ingredient in toothpastes and root canal medicaments.

\section{CONCLUSION}

The extracts of Aloe vera, black tea and coriander oil, showed significant activity against the investigated microbial strains, Streptococcus mutans and Enterococcus faecalis, which is promising. These extracts are not pure compounds and in spite of it, antimicrobial results were obtained. This recommends the potency of these extracts. The fragment of the derivation of antimicrobial compounds from plants seems lucrative as it will lead to the development of a phytomedicine to act against microbes. Isolation and purification of these phytoconstituents from plants may yield significant novel antimicrobials, as plant based antimicrobials have enormous therapeutic potential and they can serve the purpose without any adverse effects that are frequently associated with synthetic compounds.

\section{Acknowledgments}

The authors are grateful to Nano biotechnology lab of Saveetha Dental College for who facilitated and enabled us to carry out this study successfully.

\section{Funding}

This study was not supported by any organisation and was self funded.

\section{Conflict of interest}

The authors have no proprietary, financial, or other personal interest of any nature or kind in any product, service, and/or company that is presented in this article.

\section{Regulatory Statement}

This study was conducted in accordance with all the provisions of the local human subjects oversight committee guidelines and policies of: Saveetha Institute of Medical and Technical Sciences. The approval code for this study is: IHEC/SDC/BDS/003/01.

\section{REFERENCES}

1. Ellwood R, Fejerskov 0. Clinical use of fluoride. InDental caries (pp. 189-222). Blackwell Publishing Ltd:2003.

2. Marsh P,Martin MV. Oral microbiology. 4 ed. Butterworth-Heinemann: 1999.

3. Selwitz RH, Ismail Al, Pitts NB. Dental caries. Lancet. 2007 Jan 6;369(9555):51-9. doi: 101016/S0140-6736(07)60031-2. PMID: 17208642.

4. Fejerskov 0 . Changing paradigms in concepts on dental caries: consequences for oral health care. Caries Res. 2004 May-Jun;38(3):182-91. doi: 10.1159/000077753. PMID: 15153687.

5. Scheie AA, Petersen FC. The biofilm concept: consequences for future prophylaxis of oral diseases? Crit Rev Oral Biol Med. 2004 Jan 1;15(1):4-12. doi: 10.1177/154411130401500102. PMID: 14761896.

6. Featherstone JD. The science and practice of caries prevention. J Am Dent Assoc. 2000 Jul;131(7):887-99. doi:10.14219/jada.archive.2000.0307.PMID: 10916327.

7. Featherstone JD. The continuum of dental caries--evidence for a dynamic disease process. J Dent Res. 2004;83 Spec No C:C39-42. doi: 10.1177/154405910408301s08. PMID: 15286120.

8. Caufield PW, Griffen AL. Dental caries. An infectious and transmissible disease. Pediatr Clin North Am. 2000 0ct;47(5):1001-19, v. doi: 10.1016/s00313955(05)70255-8. PMID: 11059347.

9. Loesche WJ. Role of Streptococcus mutans in human dental decay. Microbiol Rev. 1986 Dec;50(4):353-80. PMID:3540569; PMCID: PMC373078.

10. Banas JA. Virulence properties of Streptococcus mutans. Front Biosci. 2004 May 1;9:1267-77. doi: 10.2741/1305. PMID: 14977543.

11. Sedgley CM, Lennan SL, Clewell DB. Prevalence, phenotype and genotype of oral enterococci. Oral Microbiol Immunol. 2004 Apr;19(2):95-101. doi: 10.1111/j.0902-0055.2004.00122.x. PMID: 14871348.

12. Rôças IN, Siqueira JFJr, Santos KR. Association of Enterococcus faecalis with different forms of periradicular diseases. J Endod. 2004 May;30(5):31520. doi:101097/00004770-200405000-00004. PMID: 15107642.

13. Orstavik D, Haapasalo M. Disinfection by endodontic irrigants and dressings of experimentally infected dentinal tubules. Endod Dent Traumatol. 1990 Aug;6(4):142-9. doi:10.1111/j.1600-9657.1990.tb00409.x. PMID: 2133305.

14. Haapasalo M, Orstavik D. In vitro infection and disinfection of dentinal tubules. J Dent Res. 1987 Aug;66(8):1375-9. doi: 10.1177/00220345870660081801.PMID:3114347

15. Distel JW, Hatton JF, Gillespie MJ. Biofilm formation in medicated root canals. JEndod. 2002 0ct:28(10):689-93. doi:10.1097/00004770-20021000000003. PMID: 12398165.

16. Makarov VV, Love AJ, Sinitsyna OV, Makarova SS, Yaminsky IV, Taliansky ME, Kalinina NO. "Green" nanotechnologies: synthesis of metal nanoparticles using plants. Acta Naturae. 2014 Jan;6(1):35-44. PMID: 24772325; PMCID: PMC3999464. 
17. Shelton RM. Aloe vera. Its chemical and therapeutic properties. Int J Dermatol. 19910ct;30(10):679-83. do: 10.1111/j.1365-4362.1991.tb02607.x. PMID: 1823544

18. Habeeb F, Shakir E, Bradbury F, Cameron P, Taravati MR, Drummond AJ, Gray Al, Ferro VA. Screening methods used to determine the anti-microbial properties of Aloe vera inner gel. Methods. 2007 Aug;42(4):315-20. doi: 10.1016/.jymeth.2007.03.004. PMID: 17560318

19. Gupta S, Saha B, Giri AK. Comparative antimutagenic and anticlastogenic effects of green tea and black tea: a review. Mutat Res. 2002 Sep;512(1):3765. do: 10.1016/s1383-5742(02)00024-8. PMID: 12220589.

20. Halder B, Pramanick S, Mukhopadhyay S, Giri AK. Inhibition of benzo[a] pyrene induced mutagenicity and genotoxicity by black tea polyphenols theaflavins and thearubigins in multiple test systems. Food Chem Toxicol. 2005 Apr;43(4):591-7. doi: 10.1016/j.fct.2005.01.002. PMID: 15721207.

21. Han C. Screening of anticarcinogenic ingredients in tea polyphenols. Cancer Lett. 1997 Mar 19;114(1-2):153-8. doi:10.1016/s0304-3835(97)04647-8.PMID: 9103276.

22. Sarkar A, Bhaduri A. Black tea is a powerful chemopreventor of reactive oxygen and nitrogen species: comparison with its individual catechin constituents and green tea. Biochem Biophys Res Commun. 2001 Jun 1;284(1):173-8. doi:10.1006/bbrc.2001.4944.PMID: 11374887.

23. Chung KT, LuZ, Chou MW. Mechanism of inhibition of tannic acid and related compounds on the growth of intestinal bacteria. Food Chem Toxicol. 1998 Dec;36(12):1053-60. doi: 10.1016/s0278-6915(98)00086-6. PMID: 9862646.

24. SakanakaS, Juneja LR, Taniguchi M. Antimicrobial effects of green tea polyphenols on thermophilic spore-forming bacteria. J Biosci Bioeng. 2000:90(1):81-5. doi:101016/s1389-1723(00)80038-9.PMID: 16232822
25. Maeda-Yamamoto M, Nagai H, Suzuki Y,Ema K, Kanda E, Mitsuda H. Changes in 0-methylated catechin and chemical component contents of 'Benifuuki'green tea (Camellia sinensis L.) beverage under various extraction conditions. Food Sci Technol Res. 2005;11(3):248-53. doi: 10.3136/fstr.11.248.

26. Burdock GA, Carabin IG. Safety assessment of coriander (Coriandrum sativum L.) essential oil as a food ingredient. Food Chem Toxicol. 2009 Jan;47(1):22-34. doi: 10.1016/j.fct.2008.11.006. Epub 2008 Nov 12. PMID: 19032971.

27. Lawrence BM. A planning scheme to evaluate new aromatic plants for the flavor and fragrance industries. p. 620-627. In: J. Janick and J.E. Simon (eds.), New crops. Wiley, New York. 1993.

28. Silva F,Ferreira S, Queiroz JA, Domingues FC. Coriander (Coriandrum sativum L.) essential oil: its antibacterial activity and mode of action evaluated by flow cytometry. J Med Microbiol. 20110ct;60(Pt 10):1479-1486 doi: 10.1099/jmm.0.034157-0. Epub 2011 Aug 23.PMID:21862758.

29. Ríos JL, Recio MC. Medicinal plants and antimicrobial activity. J Ethnopharmacol. 2005 Aug 22;100(1-2):80-4. doi: 10.1016/j.jep.2005.04.025. PMID: 15964727.

30. O'Mahony R, Al-Khtheeri H, Weerasekera D, Fernando N, Vaira D, Holton $\mathrm{J}$, Basset C. Bactericidal and anti-adhesive properties of culinary and medicinal plants against Helicobacter pylori. World J Gastroenterol. 2005 Dec 21;11(47):7499-507. doi: 10.3748/wjg.v11.i47.7499. PMID: 16437723; PMCID:PMC4725184.

31. Rani P,Khullar N. Antimicrobial evaluation of some medicinal plants for their anti-enteric potential against multi-drug resistant Salmonella typhi. Phytother Res. 2004 Aug;18(8):670-3. doi: 10.1002/ptr.1522. PMID: 15476301.

\section{Haripriya Subbaiyan} (Corresponding address)

Senior Lecturer

Department of Conservative Dentistry and Endodontics, Saveetha Dental College

Saveetha Institute of Medical and Technical Sciences, Saveetha University

162, Poonamallee High Road, Chennai 600077, Tamil Nadu, India.

Date submitted: 2020 Apr 11

E-mail: sharipriya92@gmail.com
Accept submission: 2020 Aug 25 